\author{
Andrzej GAZDA ${ }^{1}$ \\ Dušan MALINDŽÁK ${ }^{2}$
}

\title{
THE QUALITY OF THE LOGISTIC PROCESS
}

\begin{abstract}
Meeting customers' requirements with proper quality service is the major problem of logistics. Companies use various methods of quality management but it does not guarantee reaching high quality level of the logistic process. Comprehensive approach is necessary as it enables using many quality management methods and tools simultaneously.
\end{abstract}

\section{INTRODUCTION}

The origin of the term of quality dates back to the ancient times and philosophical sciences. For the first time it was used by Plato, who believed that judgments based on measurable (quantitative) criteria cannot fully describe phenomena and items. The real world is an imperfect representation of perfect ideas really existing. Quality of individual items means therefore the reached degree of perfection ${ }^{3}$.

In the following centuries many authors dealt with the issue of quality, described and characterised it. E. Kindlarski gathered over a hundred definitions of quality ${ }^{4}$. One of them was formulated by Donkelaar:

"Product (service) quality is good only when with minimum costs of use it provides maximum contribution to the health and happiness of all persons who have participated in its design, production, distribution, use, protection and recycling and distinguishes itself with minimum consumption of energy and resources as well as acceptable impact on the environment and the society"5.

This definition expresses fully and unambiguously the essence of quality and indicates all elements that should be taken into account in designing and quality assessment of products and services. It also refers to ecological aspects and the impact of products and services on the society, which is quite important today.

The history of logistics is also that long. The term of logistics was in use in the times of Leon VI, Byzantine emperor (865-912). The etymological origin of the word "Logistics" is Greek. Logizmus (calculations, attention, reasoning, plan), logistikos (calculated, logically thinking), logistics (the art of practical counting), logos (recognition), logo (to think) ${ }^{6}$.

The term "logistics" was used by Swiss general Jomini in his paper titled "Summary of the Art of War" in $1837^{7}$. He defines logistics as the art of managing movement, sup-

\footnotetext{
${ }^{1} \mathrm{PhD}$, Andrzej Gazda, The Faculty of Management, Rzeszow University of Technology, Rzeszow.

${ }^{2} \mathrm{DSc}, \mathrm{PhD}$, Eng., Dušan Malindžák, The Faculty of Management, Rzeszow University of Technology, Rzeszow.

${ }^{3}$ W. Tatarkiewicz, Historia filozofii, PWN, Warszawa 1968, s.119.

${ }^{4}$ E. Kindlarski, Jakość wyrobów, PWN, Warszawa 1988.

${ }^{5}$ A. Jazdon, Doskonalenie zarzqdzania jakościq, OPO Bydgoszcz 2001, s. 9.

${ }^{6}$ D. Malindžák, J. Takala, Projektowanie systemów logistycznych: Teoria i praktyka, EXPRES PUBLICIT s.r.o., Košice 2005, $221 \mathrm{~s}$

${ }^{7}$ D. Malindžák, Logistyka produkcyjna I., Štroffek, Košice, 1997.
} 
plies and accommodation of the attacking forces. The term of logistics was introduced in economy in the 1950s, while in Polish reference books it became more popular in the 1980 s and the 1990s.

Out of many definitions we may choose the one that presents logistics as a field of business: "In a broad sense, logistics is treated as an integrated system of shaping and controlling the processes of physical flow of goods and informative considerations oriented at reaching the most favourable relations between the quality of provided services (recipient service quality) and the level and structure of related costs ${ }^{\text {" }}$.

Quality and logistics should be closely related to each other. It is enough to compare the definitions of both these terms, in which satisfying customer's needs and the level, that is the quality of provided services, are very important. On the other hand, reference books rarely and only fragmentarily refer to the issue of quality in logistics. They lack a comprehensive, complex approach encompassing all aspects of this issue.

\section{QUALITY ASSURANCE METHODS AND SYSTEMS}

Quality assurance is the primary objective of quality management because not only quality alone but in fact quality assurance inspires trust in the supplier. Quality assurance implementation requires development of a quality assurance system including such components as: proper organisational structure, processes, procedures and assets ${ }^{9}$.

Reference books in the field of quality as well as practice of production companies demonstrate that there are many various solutions and concepts of quality assurance. In a synthetic aspect, we may properly classify these solutions and present the following description perspectives ${ }^{10}$ :

- evolutionary, presenting stages of development of the concept of quality assurance,

- $\quad$ proprietary, presenting achievements of selected and popular originators of quality assurance,

- regional, representing differentiated approach to quality assurance depending on local conditions of a given country or commonwealth.

These aspects overlay and are closely related to each other. However, we cannot determine accurate time frames of individual stages of quality assurance development because they started differently and their course was in each case different, depending on the country, region, branch of economy and even the company.

A. Hamrol and W. Mantura distinguish the following most typical stages and concepts of quality management development ${ }^{11}$ :

1. Production control

It is included in the organisational structure of the company, in production units in the production or technical department. Control functions in this case refer to a work post. The subject of the control may be the product, but also a part, unit, assembly, etc. which is obtained in the course of a production process and assessed in terms of technical quality.

\footnotetext{
${ }^{8}$ L. Garbarski, I. Rutkowski, W. Wrzosek, Marketing. Punkt zwrotny nowoczesnej firmy, PWE, Warszawa 2000, s. 436-437.

${ }^{9}$ Zarzqdzanie jakościa, red. W. Niedrzwicki, ODDK Sp. z o.o., Gdańsk 1999, s. 9.

${ }^{10}$ A. Hamrol, W. Mantura, Zarzqdzanie jakościq. Teoria i praktyka, PWN, Warszawa 2004, s. 91.

${ }^{11}$ A. Hamrol, W. Mantura, Zarzqdzanie jakościq. Teoria i praktyka, PWN, Warszawa 2004, s. 91.
} 
Therefore product orientation and acceptance function dominate. It is a control that has properties of restrictive remedial inspection. The main purpose of its results is to determine whether to accept or reject a product and remunerate or punish an employee.

2. Quality control

This type of control is based on the assumption that quality may not be forced by control, it must be developed. A more developed organisational structure occurs, closely related with quality. It mainly concerns laboratories, test and analysis units, staff units and other. Quality is taken into account not only in the technical aspect. This approach usually includes certain elements of preventive activity as well. Responsibility for quality is divided between production and management units and method of self-control is in use. Quality control in this case has features of acceptance and prevention control and uses methods of statistical quality control.

3. Quality guidance

Regulating is most important, including the functions of control and correction. Elements of planning and quality stimulation are also present. Quality guidance uses a cybernetic model with feedback, therefore it is process-oriented. It is complex, so it goes beyond the quality service which has a very important place in the organisational structure of the company. Quality guidance employs self-control and systems of faultless work. Additionally, methods of statistical control of technical process are often in use.

\section{Quality Management}

The abovementioned concepts and stages included only certain management functions, while this concept takes into account a complete set of these functions. Growth of importance of quality management was particularly distinctive in Great Britain where BS 5750 standard was introduced in 1979. It determined the requirements for quality assurance systems. In 1987 the International Organisation for Standardisation published a series of standards referred to as ISO 9000, which specify terminology related with quality management, describe different models of quality assurance, determine functional conditions for this models as well as guidelines for quality management and elements of quality assurance systems.

The third edition of ISO 9000 was introduced in 2000. It includes four standards:

- $\quad$ ISO 9000:2005 (PN-EN ISO 9000:2006) Quality management systems - Fundamentals and vocabulary.

- $\quad$ ISO 9001:2000 (PN-EN ISO 9001:2001) Quality management systems. Requirements.

- $\quad$ ISO 9004:2000 (PN-EN ISO 9004:2001) Quality management systems. Guidelines.

- $\quad$ ISO 19011:2002 (PN-EN 19011:2003) Guidelines for auditing management systems.

The next edition of ISO 9001 standard was introduced in 2008 and since 2009 it has been in use in Poland as PN-EN ISO 9001:2009. Minor changes introduced in this edition mainly concern more specific and accurate formulation of certain terms and provisions ${ }^{12}$.

Changes were also introduced in 2009 to ISO 9004 standard, that is Polish PN-EN ISO 9004:2010. Above all, the name was changed. The current name is: "Quality management oriented on permanent success of an organisation. Quality management approach"13.

\footnotetext{
${ }^{12}$ PN-EN ISO 9001, PKN Warszawa 2009.

${ }^{13}$ P. Rogala, Zarzqdzanie wg nowej normy ISO 9004, „Problemy Jakości” 2011, nr 3, s. 9.
} 
Complete, accurate and detailed implementation of the said standards in a company as well as meeting all the related requirements do not mean that the company has a comprehensive and complex management strategy. The concept that is currently referred to as the best one, including all issues related with quality management implementing all management functions and involving all employees of the company, is "Total Quality Management" (TQM).

According to S. Tkaczyk: "Total Quality Management is a people-oriented management system purpose of which is constant increase in satisfaction of customers gained at really constantly decreasing costs. The TQM is a complex system approach (not a selected field or programme) and an integral part of the high-level strategy; this system functions horizontally, crosswise to functional sections and departments, involving all employees of the entire company; it goes in both directions beyond the company in order to incorporate the supply and distribution chains. The TQM emphasises teaching and adaptation to the process of constant changes as the key to the success of the organisation" ${ }^{\text {.14 }}$.

The integrated management system is an interesting idea. More and more often in theory and practice of company management are taken actions oriented at integration of individual autonomous management subsystems. One general management system may encompass ${ }^{15}$ :

- $\quad$ quality according to ISO 9001 ,

- environment according to ISO 14001,

- $\quad$ occupational safety and health according to PN-N-18001 (BS 8800),

- finances,

- logistics.

However, most often integration encompasses only quality, environment and occupational safety management systems and sometimes quality systems implemented in individual branches of industry. Logistics is treated as a separate field of management.

\section{THE CONCEPT OF THE LOGISTIC PROCESS QUALITY ASSURANCE SYSTEM}

The logistic process may be implemented with use of all of the methods and quality management systems described above. However, they do not guarantee reaching the goal of high level of customer service because they do not include all aspects of logistic process management. Furthermore, research carried out in Polish companies indicated that many quality management tools are used only to a small extent (tab. 1).

\footnotetext{
${ }^{14}$ S. Tkaczyk, Inżynieria jakości a inżynieria materiałowa, IOiZwP „Orgmasz”, Warszawa 2000, s. 33.

${ }^{15}$ A. Repetski, Doświadczenia z wdrażania systemów zarzqdzania środowiskowego (SZŚ) w świetle norm ISO serii 14000, „Problemy Ocen Środowiskowych” 1998, nr 2-3.
} 
Tab. 1. Quality management system improvement tools being implemented (results of research of 2006 and 2007, comparison of segments depending on the number of employees and origin of the capital; percentage of indications)

\begin{tabular}{|c|c|c|c|c|c|c|c|c|c|c|}
\hline \multirow{3}{*}{$\begin{array}{l}\text { Implemented } \\
\text { management } \\
\text { system im- } \\
\text { provement tools }\end{array}$} & \multicolumn{6}{|c|}{ Number of employees } & \multicolumn{4}{|c|}{ Capital } \\
\hline & \multicolumn{2}{|c|}{ up to 50} & \multicolumn{2}{|c|}{$51-250$} & \multicolumn{2}{|c|}{ over 250} & \multicolumn{2}{|c|}{ foreign } & \multicolumn{2}{|c|}{ Polish } \\
\hline & $\begin{array}{l}2006 \\
\mathrm{~N}=64\end{array}$ & $\begin{array}{c}2007 \\
N=63\end{array}$ & $\begin{array}{c}2006 \\
\mathrm{~N}=112\end{array}$ & $\begin{array}{c}2007 \\
\mathrm{~N}=147\end{array}$ & $\begin{array}{l}2006 \\
\mathrm{~N}=83\end{array}$ & $\begin{array}{c}2007 \\
\mathrm{~N}=90\end{array}$ & $\begin{array}{r}2006 \\
N=73\end{array}$ & $\begin{array}{l}2007 \\
\mathrm{~N}=66\end{array}$ & $\begin{array}{c}2006 \\
\mathrm{~N}=186\end{array}$ & $\begin{array}{l}2007 \\
N=234\end{array}$ \\
\hline $\begin{array}{l}\text { Environmental } \\
\text { management } \\
\text { system }\end{array}$ & 15.63 & 20.63 & 42.86 & 38.78 & 56.63 & 61.11 & 52.05 & 74.24 & 36.02 & 65.38 \\
\hline \begin{tabular}{l}
\multicolumn{2}{l}{ Occupational } \\
safety and \\
health man- \\
agement system
\end{tabular} & 20.31 & 3.17 & 24.11 & 14.29 & 55.42 & 28.89 & 43.84 & 31.82 & 29.03 & 11.97 \\
\hline $\begin{array}{l}\text { Total Produc- } \\
\text { tive Mainte- } \\
\text { nance/5S }\end{array}$ & 10.94 & 14.29 & 17.86 & 19.73 & 27.71 & 36.67 & 24.66 & 33.33 & 17.20 & 20.94 \\
\hline $\begin{array}{l}\text { Self- } \\
\text { assessment/ } \\
\text { assessment } \\
\text { according to } \\
\text { quality awards } \\
\text { criteria }\end{array}$ & 12.50 & 17.46 & 12.50 & 10.90 & 20.48 & 21.11 & 15.07 & 7.58 & 15.05 & 17.09 \\
\hline $\begin{array}{l}\text { Lean } \\
\text { Management }\end{array}$ & 9.38 & 15.87 & 15.18 & 8.84 & 26.51 & 25.56 & 24.66 & 34.85 & 14.52 & 9.83 \\
\hline $\begin{array}{l}\text { Balanced } \\
\text { scorecard }\end{array}$ & 23.44 & 7.94 & 16.07 & 9.52 & 19.28 & 23.33 & 17.81 & 21.21 & 19.35 & 11.11 \\
\hline Six Sigma & 6.25 & 3.17 & 9.82 & 7.48 & 14.46 & 14.44 & 13.70 & 19.70 & 9.14 & 5.56 \\
\hline
\end{tabular}

Source: Prepared on the basis of: M. Urbaniak, Przedsiębiorstwa i koncepcje zarzadzania, „Problemy Jakości” 2007, nr 11, s. 24.

Individual quality management methods and tools are mostly used by large companies with foreign capital. It was confirmed in independent research in companies in the automotive and aviation industry. On this basis we may say that the most complex logistic process quality management system that may also be introduced in other companies has been developed and used at United Technologies Corporation.

Companies belonging to the UTC implement the system of Achieving Competitive Excellence. It is a system of continuous improvement in all fields and aspects of company functioning, in particular in terms of operational activity management and in production logistics. It enables achieving company goals through mobilisation of employees in their everyday activities ${ }^{16}$.

The system consists of ten "tools". These are popular work and management organising methods and techniques, in particular based on Lean Management but within the framework of ACE used in a comprehensive and consistent manner. The tools are integrated, effective and may evolve depending on specific application. They encompass methods of communication and measures for monitoring of activity.

\footnotetext{
${ }^{16}$ „Wiadomości”. Pismo Wytwórni Sprzętu Komunikacyjnego „PZL-Rzeszów” S.A. 2002, nr 5, s. 10.
} 
The first one is $5 \mathrm{~S}+1$ method. Its objective is to simplify, improve and create safe work conditions. It reduces wasted time, visually arranges the workplace, creates friendly and safe work environment.

Use of $5 \mathrm{~S}$ method consists in removal of useless items from the workplace, putting useful items in their specific place and keeping production department and the entire plant impeccably clean. As these activities are performed systematically and work methods are constantly improved, a firm system guaranteeing order and tidiness is created. It is not only tidying, though, it is a process of thorough changes in the company culture, based on management visualisation, standardisation of processes and teamwork. The sixth " $\mathrm{S}$ " is Safety, which means safe work in a safe environment

The second tool is Single Minute Exchange of Die (SMED), that is team reduction of machine tooling exchange time. Activities are focused on reduction of down time between production of the last part of one series and starting production of the first part of another series. The positive effect is increase in machines and equipment capacity, increased work efficiency, standardisation of work methods and optimisation of series sizes.

The third tool, Total Productive Maintenance is a concept aimed at increasing productivity and efficiency of processes related with workflow maintenance through increasing creative involvement of employees participating in such processes.

The major issue related with the fourth tool of model methods is grouping similar parts in so-called families in order to standardise methods of production. This promotes elimination of activities that do not provide added value, avoiding losses and shortening of the production cycle.

The most important problem to be solved with use of the fifth tool: Quality Clinic Process Chart - QCPC, is organisation of a database system, which enables constant improvement of the process and solving quality-related problems. Each employee may present comments on their workpost, describing everything that hinders reaching the required production quality in an appropriate questionnaire. Employees' remarks also refer to occupational safety and health threats.

Gathering information every day facilitates taking immediate corrective actions. Additionally, all reported issues are categorised according to their importance and suggested solution at the weekly meetings of the QCPC team. If there is a problem that cannot be solved by the team, it is passed on to the "Quality Clinic".

The sixth tool is the RCCA method (Root Cause Corrective Action), consisted in developing standard decisions referring to specific original causes. This tool is used in order to prevent reappearance of problems.

The basic issue in the regression analysis of the market, which is the seventh tool, is to identify external and internal customers and provide feedback that will make each employee understand their needs. Data from the market and the customers, concerning quality of products must reach every workpost, every employee. This will facilitate improvement of quality of products and services.

The eighth tool, error prevention (Poka Yoke) is strengthening the process against errors, which consists in active controlling of potential sources of inconsistency, so that it would be possible to identify an error before it becomes inconsistency. When the error is found, production is stopped or a proper action is taken to prevent occurrence of inconsistency as a result of such error. While monitoring potential sources of errors in each phase of the process, we may found and correct inconsistencies at their very source, which means that this tool may prevent errors through elimination of their causes. 
Process validation is the ninth tool and it enables process management, understanding, controlling and monitoring deviations. Validation or certification of the process is used for stabilising it and maintaining at the statistically controlled level. Certification of processes is based on statistical methods and includes measurable and non-measurable characteristics. The result of using this tool is repeatable production of high quality items.

The tenth tool is process management which consists in permanent and consistent implementation of preventive methods in process improvement. It enables determining the optimum process and identifying its weak points. It eliminates activities that do not bring added value to the process.

Beside the described tools, the Kaizen system is in use. It consists in making slight improvements in a continuous series with use of the existing tools or systems, through the employees of proper company departments for the benefit of which improving actions are taken. Such activities mostly do not require involving significant financial assets or external experts. In Kaizen, standardising and a system that supports maintaining the level of changes are essential. It is also related with the principle which says that no further actions may be taken if the level of previous change is not maintained.

We may use either all the abovementioned tools, the chosen ones or even only certain parts of these tools. However, positive effects will not last if they are not supported by the organisational structure facilitating changes in the company operations and by professionally trained personnel.

Achieving Competitive Excellence system is based on three basic components:

- $\quad$ quality management principles developed by Yuzuru Ito - ITO University carries out weekly training sessions within this scope for all employees, in particular directors and managers,

- a system which helps the organisation identify and solve problems, improve processes and supports strategic thinking,

- $\quad$ professionalism, dutifulness and involvement of all employees and the entire organisation.

Training company employees is essential. All employed persons have the possibility to participate in a free training and improve their qualifications, mainly within the framework of the scholar programme in which course fees as well as the costs of materials and textbooks are covered.

ACE system is not a one-off action - within its framework teams of employees systematically reach four successive levels:

- qualifications,

- bronze,

- silver,

- gold.

It is the primary motive for constant improvement and consistent use of ACE tools.

It is hard to define and measure the results of implementation of the system. However, if we take a look at individual companies of the UTC concern, we may notice that they beat their competition, gaining contracts, for instance to supply aircraft engines. In the times of the today's crisis, companies not only collapse, but also develop while UTC buys another ones in the aviation industry.

All companies within the concern carry out an annual survey among all their employees. Answers are helpful in improving the company activity and reflect results of the implemented system. The survey carried out at WSK "PZL - Rzeszów" presented good 
economic condition of the company and over $80 \%$ of the respondents said that the good points of that company are care of quality and following occupational safety and health rules, whereas around $80 \%$ of them referred to the company as a good workplace.

\section{CONCLUSIONS}

Achieving Competitive Excellence system may be implemented and used not only at the UTC but also in other companies. However, it always requires adjusting the system principles to the specific character of individual companies as well as monitoring and analysing results obtained in implementation of the modified system.

Implementation of the ACE system is not easy. Costs of preparation of individual system components, training of employees and making necessary organisational changes must be incurred.

Good preparation and consistency are vital in implementation, and in particular in employing the developed solutions in everyday business. Therefore change in mentality of all employees including the management is very important, so that the introduced and implemented actions would be the work culture on each post.

The most significant threat related with implementation and functioning of the system is lack of consistent actions of the management and employees of the company. Low qualifications of the personnel may also be a threat, therefore particular attention must be paid to training and professional education as well as all company staff. Problems may also occur if other, competitive companies employ the same or similar solutions. But ACE system is flexible enough to enable introduction of other, new components, which makes it possible to beat the competition.

Still most important chances lie in the improvement of the company structure and organisation, reduction of costs. But above all, implementation of the ACE system and its everyday functioning may contribute to improvement in management and functioning of the company, also in the area of logistics, which is followed by improvement of its condition and market position.

\section{LITERATURE}

[1] Tatarkiewicz W., Historia filozofii, PWN, Warszawa 1968, s.119.

[2] Kindlarski E., Jakość wyrobów, PWN, Warszawa 1988.

[3] Jazdon A., Doskonalenie zarzadzania jakościa, OPO Bydgoszcz 2001, s.9.

[4] Malindžák D., Takala J., Projektowanie systemów logistycznych: Teoria i praktyka, EXPRES PUBLICIT s.r.o., Košice 2005. 221 s.

[5] Malindžák, D. Logistyka produkcyjna I., Štroffek, Košice, 1997.

[6] Garbarski L., Rutkowski I., Wrzosek W., Marketing. Punkt zwrotny nowoczesnej firmy, PWE, Warszawa 2000, s. $436-437$.

[7] Zarzqdzanie jakościa, red. W. Niedrzwicki, ODDK Sp. z o.o., Gdańsk 1999, s. 9.

[8] Hamrol A., Mantura W., Zarzadzanie jakościq. Teoria i praktyka, PWN, Warszawa 2004, s. 91.

[9] PN-EN ISO 9001, PKN Warszawa 2009.

[10] Rogala P. Zarzqdzanie wg nowej normy ISO 9004, „Problemy Jakości” 2011, nr 3, s. 9.

[11] Tkaczyk S. Inżynieria jakości a inżynieria materiałowa, IOiZwP „Orgmasz”, Warszawa 2000, s. 33.

[12] Repetski A., Doświadczenia z wdrażania systemów zarzadzania środowiskowego (SZŚ) $w$ świetle norm ISO serii 14000, „Problemy Ocen Środowiskowych” 1998, nr 2 - 3.

[13] Urbaniak M., Przedsiębiorstwa i koncepcje zarządzania, „Problemy Jakości” 2007, nr 11, s. 24. 
[14] „Wiadomości”. Pismo Wytwórni Sprzętu Komunikacyjnego „PZL-Rzeszów” S.A. 2002, nr 5, s. 10.

\section{JAKOŚĆ PROCESU LOGISTYCZNEGO}

Zaspokojenie wymagań klientów za pomocą odpowiedniej jakości serwisu jest podstawowym zagadnieniem logistyki. Przedsiębiorstwa stosują różne metody zarządzania jakością, ale nie gwarantuje to osiagnięcia wysokiego poziomu jakości procesu logistycznego. Niezbędne jest podejście całościowe, pozwalające na zastosowanie jednocześnie wielu metod i narzędzi zarządzania jakością.

DOI: 10.7862/rz.2012.zim.19 